\title{
Evaluation of Phyllanthus amarus leaf meal for hepato-nephro-protective potentials in broiler chickens
}

\author{
Unigwe, Cyprian Robinson “*, Esan Oluwaseun Olanrewaju ${ }^{3}$, Enibe Francis ${ }^{3}$, Igwe, Kalu \\ Kalu. ${ }^{1}$, Igwe, Ikechukwu. Reginald ${ }^{1}$, Ajayi, John Olurotimi ${ }^{2}$, \\ Koleosho, Sulaimo Adisa ${ }^{2}$, Shobowale, Olanrewaju Monsuru ${ }^{2}$ and \\ Balogun, Fatima Adeola².
}

\author{
${ }^{1}$ Department of Vet. Biochemistry and Animal Production, Michael Okpara University of \\ Agriculture, Umudike, Abia State, Nigeria. \\ ${ }^{2}$ Federal College of Animal Health and Production Technology, Ibadan, Oyo State, Nigeria. \\ ${ }^{3}$ Department of Vet. Medicine, University of Ibadan, Oyo State, Nigeria.
}

Accepted June, 2021 and Published July, 2021

\begin{abstract}
Phyllanthus amarus is an important medicinal plant that is widely distributed in all tropical and subtropical regions of the planet and has the ability to prevent and treat several human and animal diseases but has been associated with pathological defects on various organs on dose-dependent pattern. This study was carried out to evaluate Phyllanthus amarus leaf meal (PALM) for hepato-nephro-protective potentials in broiler chickens. One hundred and twenty (120) day old marshal broiler chickens were used for the experiment that lasted for 56 days. The birds were randomly allotted to five treatments of $T_{0}$ (control, no PALM), $T_{1}\left(2.5 \mathrm{~g} / \mathrm{kg}\right.$ PALM), $T_{2}\left(5.0 \mathrm{~g} / \mathrm{kg}\right.$ PALM), $T_{3}\left(7.5 \mathrm{~g} / \mathrm{kg}\right.$ PALM) and $T_{4}(10 \mathrm{~g} / \mathrm{kg}$ PALM) in a complete randomized design (CRD). Each treatment was replicated thrice with 8 birds per replicate. The birds were fed with commercial Top ${ }^{\circledR}$ feed and water was given ad-libitum. At the end of the experiment, blood was aseptically collected via venipuncture from a randomly selected bird per replicate to determine the serum biochemical parameters and later was humanely sacrificed for organs harvest. The liver and kidney were carefully dissected out and fixed in buffered 10\% formalin for histological study. The biochemical data were subjected to analysis of variance (ANOVA) and statistical difference in means was separated using Duncan's Multiple Range Test. The histo-pathological slides were interpreted by experts. ALT for $T_{1}-T_{4}$ were statistically similar but differed significantly $(P<0.05)$ from $T_{I}$. The ALP, however, showed $T_{2}-T_{4}$ differing significantly $(P<0.05)$ from $T_{0}$ and $T_{1}$. The uric acid was highest in $T_{4}$ and differed significantly $(P<0.05)$ from other groups. The urea was highest in quantity in $T_{3}$ and $T_{4}$ and as well differed significantly $(P<0.05)$ from other treatments. Therefore, the results showed significant differences $(P<0.05)$ across treatment groups except for AST. PALM gradually increased the ALT, ALP, uric acid and urea in a dose dependent manner across treatments except urea that slightly decreased at $T_{4}$. The findings indicated that the PALM had varied time and dose dependent pathological effects on the liver and kidney of treated groups. It can therefore be concluded that PALM enhances serum biochemical parameters and has deleterious effects on the cyto-architecture of liver and kidney. It is recommended that PALM (crude) up to $2.5 \mathrm{~g} / \mathrm{kg}$ should not be administered protractedly in chickens since it could constitute damage to visceral organs.
\end{abstract}

Keywords: Broiler, Kidney, Liver, Pathology, Phyllanthus amarus, Serum biochemistry

*Corresponding author:

email: robinsonunigwe@gmail.com

Tel: +234-803 7707965 


\section{INTRODUCTION}

In the recent times, focus on plant research has increased all over the world, and a large body of evidence has been collected to show the immense potential of medicinal plants used in various traditional systems [1]. Herbal medicines are believed to be safer than synthetic medicine because phytochemicals in the plant extract target its biochemical pathways [2]. Phyllanthus amarus is widely distributed in all tropical and subtropical regions of the planet [3]. In Nigeria, it is called "Oyomokeisoamank edem" in Efik, "Iyin Olobe" in Yoruba and "Ebebenizo" in Bini [4]. $P$. amarus has various groups of compounds such as alkaloids, flavanoids, hydrolysable tannins, major lignans and polyphenols $[5 ; 6]$. Lignans like phyllanthin and hypophyllanthin, flavonoids like quercetin were isolated from the leaves of P. amarus [7]. Phyllanthus genus is a plant of the family Euphorbiaceae and has approximately 800 species which are found in tropical and subtropical countries of the world [8]. Its effect in excretory system is due to its antiurolithic property and is used in the treatment of kidney/gallstones, other kidney and liver related problems, appendix inflammation and prostate problems $[9 ; 10 ; 11]$. The whole plant extract is used in urinary problems and swelling of liver. In the 1990s, a major reorganization of the Phyllanthus genus was conducted which classified $P$. amarus as a type of $P$. niruri [12]. The anti-nutritional compounds contained in $P$. amarus include oxalate, phytate, hydrogen cyanide, nitrate and tannin [13].

Serum biochemistry refers to chemical analysis of blood serum. A profile of tests can be combined to evaluate renal function and hepatic functions. P. amarus, like other tropical tree leaves contains some bioactive compounds which may affect nutrient utilization, haematological and serum biochemical parameters in animals [14]. Due to the many applications of $P$. amarus plant in ethnomedicine, there is the need to investigate its effect on some organs using serum biochemical indices and cyto-architecture of the visceral organs before using it as pharmacological agent in poultry production.

\section{MATERIALS AND METHODS Site of the study}

The experiment was carried out at the student's project site of the Federal College of Animal Health and Production Technology, Moor Plantation, Ibadan, Oyo State, Nigeria. Ibadan is located approximately on longitude $3^{\circ} 5^{\prime}$ to $4^{\circ}$ $36^{\prime} \mathrm{E}$ and latitude $7^{\circ} 23^{\prime}$ to $7^{\circ} 55^{\prime} \mathrm{N}$ [15]. Ibadan has a tropical wet and dry climate, with a lengthy wet season. It has mean total rainfall of 9,233.60 mm, mean maximum and minimum temperatures of $39.82{ }^{\circ} \mathrm{C}$ and $22.5{ }^{\circ} \mathrm{C}$ respectively [16] and relative humidity of $74.55 \%$.

\section{Ethical consideration}

Ethical conditions governing the conduct of experiments with life animals were strictly observed as stipulated by Ward and Elsea [17]. The experimental protocol was approved by the ethical committee for the use of animals for experiment, Federal College of Animal Health and Production Technology, Ibadan, Oyo State, Nigeria.

\section{Preparation of Leaf Meal}

The Phyllanthus amarus leaves used were obtained from the botanical garden at the onset of rainy season (May, 2019) of the above named institution. The plant was identified and authenticated by a plant taxonomist with $\mathrm{v}$ o u c h e r s p e i m e n (FCAH\&PT/SLT/2017/021) kept in the institutional herbarium for referral purposes. The leaves were air dried to crispiness, while still retaining the green colour. The dried leaves were ground with electric grinding machine (Sonik $^{\circledR,}$ Model SB-464) to produce $P$. amarus leaf meal (PALM). It was stored in air-tight container and kept in the fridge till used.

\section{Management of the birds}

The poultry pen was cleaned and washed with a solution of detergent, disinfected with solution of Dettol $^{\circledR}$ and later Azinol ${ }^{\circledR}$ (diethyl-2Is o propyl-6-methylprimidin-4-yl phosphorotionate), at manufacturer's recommended dilution. The pen was left without stocking for one week before the arrival of the chicks to enable disinfectant residues' elimination. The floor litter was laid with $5 \mathrm{~cm}$ thick wood-shavings. On the arrival 
of the chicks, anti-stress solution (mixture of water, glucose and multivitamin) was served to them. Routine vaccinations (NDV i/o, NDV lasota and IBD vaccine) as prescribed by the Veterinarian were strictly followed during two weeks of acclimatization whereas the Commercial starter feed (Top Feed ${ }^{\mathbb{B}}$ ) and water were served ad libitum. After acclimatization, the birds were allocated to the five treatments. Fresh feed (Commercial Starter feed; 3,200 $\mathrm{Me} / \mathrm{Kcal} / \mathrm{Kg}, \mathrm{CP}=22 \%$ and Finisher Top $\mathrm{Feed}^{\circledR} ; 2800 \mathrm{Me} / \mathrm{Kcal} / \mathrm{Kg}, \mathrm{CP}=18 \%$, were purchased and used for the experiment) and clean borehole water were given to them by $7 \mathrm{am}$ and $5 \mathrm{pm}$ daily ad libitum throughout the experiment. The PALM was measured and given as stated above throughout the experimental period.

\section{Study Design}

One hundred and twenty (120) day old unsexed Marshal broiler chicks were used for the experiment. Each grade of supplement represented treatment and was represented as $T_{0}$ (control, no PALM), $\mathrm{T}_{1}\left(2.5 \mathrm{~g} / \mathrm{kg}\right.$ PALM), $\mathrm{T}_{2}$ $(5.0 \mathrm{~g} / \mathrm{kg}$ PALM $), \mathrm{T}_{3}(7.5 \mathrm{~g} / \mathrm{kg}$ PALM $)$ and $\mathrm{T}_{4}$ $(10 \mathrm{~g} / \mathrm{kg}$ PALM $)$. Each treatment was replicated thrice with a replicate having 8 birds. Birds were allotted to treatments using completely randomized design. The experiment lasted for eight weeks (56 days).

\section{Blood and organ collection and analyses}

At the end of the eight weeks (56 days) of study, $2 \mathrm{ml}$ of blood was aseptically collected from a bird per replicate through the jugular veins, emptied into a plain (without anticoagulant) test tube and allowed to coagulate to produce sera for serum biochemistry according to the methods described by Okeudo et al [18]. A bird was randomly selected from each group and sacrificed humanely at the Humane Slaughter Laboratory, Department of Veterinary Pathology/Microbiology, University of Ibadan, Nigeria. The liver and kidney were dissected out and fixed in buffered $10 \%$ formalin for histo-morphological preparation. The tissues were dehydrated in ascending grades of ethanol, cleared in xylene and embedded in paraffin wax and were stained according to Drury et al [19]. Photomicrographs of the desired sections were made for further observations at the Department of Veterinary Pathology, University of Ibadan, as described by Ewuola [20].

\section{Statistical analysis}

Serum biochemistry data obtained were subjected to one-way analysis of variance (ANOVA) using Statistical Package for Social Sciences version 17 program (SPSS Inc., Chicago IL, USA). Separation of statistical means was done with Duncan's Multiple Range Test [21]. The patho-morphological plates were subjected to expertise comparison for lesions' detection and interpretation.

\section{RESULTS}

\section{Serum Biochemical Parameters}

Table 1 shows the serum biochemical parameters of broiler chickens administered Phyllanthus amarus leaf meal (PALM) supplement. All the treatment groups showed a steady rise in AST, ALT, ALP, UA and urea as the concentration of PALM progressively increased. There was no significant difference $(\mathrm{P}<0.05)$ among treatment groups as regards AST. The ALT showed that $T_{1}-T_{4}$ were statistically the same $(\mathrm{P}>0.05)$ but differed from $\mathrm{T}_{1}(\mathrm{P}<0.05)$. ALP concentrations in $\mathrm{T}_{2}-\mathrm{T}_{4}$ demonstrated no significant difference $(\mathrm{P}>0.05)$ but differed from $\mathrm{T}_{0}$ and $\mathrm{T}_{2}(\mathrm{P}<0.05)$. Group $T_{4}$ of UA was significantly different $(\mathrm{P}<0.05)$ from $\mathrm{T}_{0}-\mathrm{T}_{3}$. In the same vein, $\mathrm{T}_{2}$ and $\mathrm{T}_{3}$ as well differed significantly from $\mathrm{T}_{0}$ and $\mathrm{T}_{1}$ $(\mathrm{P}<0.05)$. The urea showed that $\mathrm{T}_{4}$ and $\mathrm{T}_{3}$ differed significantly $(\mathrm{P}<0.05)$ from $\mathrm{T}_{1}$ and $\mathrm{T}_{2}$ $(\mathrm{P}>0.05)$ and $\mathrm{T}_{0}$. The gradation showcased by the present results pointed to the fact that PALM could be implicated in the progressive expression of higher enzymes when its concentration increased. 
Table 1: Serum biochemical parameters of broiler chickens fed Phyllanthus amarus leaf meal (PALM) supplemented diets

\begin{tabular}{llllll}
\hline Parameters & $\mathrm{T}_{0}$ (control) & $\mathrm{T}_{1}(2.5 \mathrm{~g} / \mathrm{kg})$ & $\mathrm{T}_{2}(5 \mathrm{~g} / \mathrm{kg})$ & $\mathrm{T}_{3}(7.5 \mathrm{~g} / \mathrm{kg})$ & $\mathrm{T}_{4}(10 \mathrm{~g} / \mathrm{kg})$ \\
\hline AST $(\mathrm{iu} / \mathrm{L})$ & $198.00 \pm 1.15$ & $194.15 \pm 2.01$ & $197.50 \pm 0.44$ & $203.00 \pm 1.00$ & $205.00 \pm 1.80$ \\
ALT $(\mathrm{iu} / \mathrm{L})$ & $23.00 \pm 1.00^{\mathrm{b}}$ & $26.50 \pm 1.04^{\mathrm{a}}$ & $28.50 \pm 1.32^{\mathrm{a}}$ & $30.50 \pm 1.53^{\mathrm{a}}$ & $36.00 \pm 2.08^{\mathrm{a}}$ \\
ALP $(\mathrm{iu} / \mathrm{L})$ & $64.00 \pm 1.15^{\mathrm{b}}$ & $72.6 \pm 1.50^{\mathrm{b}}$ & $80.05 \pm 1.08^{\mathrm{a}}$ & $82.25 \pm 1.03^{\mathrm{a}}$ & $84.80 \pm 0.91^{\mathrm{a}}$ \\
UA (mg/dL) & $4.24 \pm 0.11^{\mathrm{c}}$ & $5.43 \pm 0.20^{\mathrm{c}}$ & $5.78 \pm 0.16^{\mathrm{b}}$ & $5.92 \pm 0.07^{\mathrm{b}}$ & $6.21 \pm 0.17^{\mathrm{a}}$ \\
Urea (mg/dL) & $3.50 \pm 0.15^{\mathrm{c}}$ & $4.97 \pm 0.06^{\mathrm{b}}$ & $5.07 \pm 0.05^{\mathrm{b}}$ & $6.15 \pm 0.16^{\mathrm{a}}$ & $5.47 \pm 0.25^{\mathrm{a}}$ \\
\hline
\end{tabular}

a,b,c: means with different superscripts on the same row are statistically different $(\mathrm{P}<0.05)$

Key: AST $=$ Aspartate aminotransferase, ALT $=$ Alanine Aminotransferase ALP $=$ Alkaline Phosphatase, $\mathrm{UA}=$ Uric acid

\section{Histo-pathological Effects on Organs \\ Liver}

The results of this experiment (Fig. 1) revealed that the administration of PALM at 2.5, 5, 7.5, and $10 \mathrm{~g} / \mathrm{kg}$ showed varied histo-pathological defects as opposed to the control in the liver. Meanwhile, all the plates had closely packed hepatic cells. At the dose of $2.5 \mathrm{~g} / \mathrm{kg}$, the liver showed widespread and moderate vacuolar change of hepatocytes whereas $5 \mathrm{~g} / \mathrm{kg}$ dose worsened the distortion to multiple foci of marked vacuolar change of hepatocytes. Nevertheless, when the doses increased to 7.5 and $10 \mathrm{~g} / \mathrm{kg}$, the hepatocytes had finely reticulated cytoplasmic appearance which also points to hepatotoxicity.

\section{Kidney}

The results on the histo-pathology of the kidney (Fig. 2) showed varying levels of cytoarchitectural distortions as PALM was orally administered at $2.5,5$ and $7.5 \mathrm{~g} / \mathrm{kg}$ doses as opposed to the control that appeared normal. Likewise, the $10 \mathrm{~g} / \mathrm{kg}$ plate showed no visible distortion of renal architecture for a reason that could not be contemplated. At the dose of 2.5 $\mathrm{g} / \mathrm{kg}$, the renal tubule appeared swollen (hydropic change) whereas at $5 \mathrm{~g} / \mathrm{kg}$, there were multiple foci of tubular degeneration and necrosis while there was moderate congestion of interstitial blood vessels when the dose rose to $7.5 \mathrm{~g} / \mathrm{kg}$.

\section{DISCUSSION \\ Serum Biochemical Parameters}

AST, ALP and ALT are biomarkers of hepatic integrity and to a certain level can be used to assess the extent of hepatocellular damage; the ALT activities however, give more valuable information relevant to the integrity of the hepatocyte than others [22]. This trend could be a pointer that this test ingredient had a stressor effect on some muscles and organs, particularly liver and kidney. Alanine aminotransferase is a key enzyme in the biotransformation and detoxification of various toxicants, reactive oxygen species and endo- and xenobiotics [23]. ALT activity as an index has been used as an indicator of liver function and elevated levels are monitored in liver malfunction [24]. The increase of the activity of ALP in serum is mainly due to the leakage of enzymes from the liver cells into the blood stream, which gives an indication of hepatotoxicity [25]. Higher activities of serum AST and ALT are possibly the result of liver disease, probably because of oxidative damage to the tissue [26]. Thus, ALT can be used as marker to assess the extent of liver cells damage [27]. Similarly, AST belongs to the class of enzymes present in the cytoplasm and mitochondria and various types of tissue, though high concentrations are primarily found in liver and muscles [28]. According to Kuttappan et al [29], an increase in the AST level indicates liver damage caused by the metabolism of dietary therapeutic 
compounds and additives. However, the present study runs contrary to the finding of who stated that the methanol extract of Phyllanthus amarus leaves $\left(50-800 \mathrm{mg} \mathrm{kg}^{-1}\right)$ caused a statistically significant $(\mathrm{P}<0.05$ student's t-test $)$ decrease in the levels of total cholesterol, AST, ALT, urea, uric acid, total protein, prostatic, alkaline and acid phosphatases.

\section{Histo-Pathological Effects on Organs}

The historic role of medicinal herbs in the treatment and prevention of diseases, and their role as catalysts in the development of pharmacology do not, however, assure their safety for uncontrolled use by an uninformed public [31]. The results of this experiment revealed that the administration of $P$. amarus caused functional hepatotoxicity and nephrotoxicity with respect to indicators such as ALT, ALP and AST and uric acid respectively in P. amarus -treated birds compared to control (Table 1). Although establishing a robust link between exposure to test substance and a given pathological outcome can be difficult at times, distinguishing hormone-like effects from those mediated by non-endocrine mechanisms such as direct cytotoxicity or physiological stress is often challenging [32]. One reason is that most tissues exhibit a limited range of morphological and physiological responses to adverse stimuli; consequently, few chemically-induced microanatomic changes are specific to a particular class of substances, or are even unambiguously indicative of toxicosis [33]. Among the numerous functions of the liver is the processing of nutrients absorbed from the intestine and secretion of an alkaline fluid (bile) which functions in the digestion of fat and toxic substance removal from the living organism [34]. According to Soetan and Oyewole [35], anti-nutrients may present some activities which though not deeply understood, but may cause histological changes in animals. The liver health and functionality are assessed based on serum ALT, ALP and AST enzymes activities, as the cell damage caused by metabolic pressure and hypertension ease the liberation of these cellular enzymes into the serum [36].

The liver on treatments 2.5 and $5 \mathrm{~g} / \mathrm{kg}$ were only mildly affected and were in the process of coping with the insult since Nayak et al. [37] stated that swelling with nonlipid cytoplasmic vacuolation of diffusely distributed hepatocytes is seen consistently after mild acute and subacute liver injury and that morphological and biochemical investigations showed that cytoplasmic vacuolation of liver cells following low doses of toxins is due to excess accumulation of glycogen, predominantly of the mono-particulate form. Closely packed hepatic cells are normal liver cells and they arise due to blood-filled sinusoids and also lie adjacent to canaliculi into which bile is secreted [38]. Therefore, that the liver architecture demonstrated closely packed hepatic plates in all the slides is a suggestion of mild effect on cyto-architecture. It is noteworthy that $P$. amarus contains alkaloids and lots of antioxidants [39] which have been given to apparently healthy birds. Antioxidants are essential for alleviation of oxidative stress, but the indiscriminate and protracted intake of it may present their toxic effects by inducing oxidative stress [40]. The possible deduction from these results is that secondary metabolites, which are largely responsible for therapeutic or pharmacological activities of medicinal plants [41] may also account for their toxicity when there are dose and time dependent abuses (prolongation of intake as witnessed in the present study). Cellular necrosis is not induced by stimuli intrinsic to the cells as in programmed cell death (PCD), but by an abrupt environmental perturbation and departure from the normal physiological conditions [42]. $P$. amarus in this study did not demonstrate hepatoprotective effect. Srirama et al [43] pointed out that phyllanthin and hypophyllanthin (found in PALM) may not be the only compounds responsible for hepatoprotective property. According to Londhe et al [44], hepatoprotective property of P. amarus is attributed to amariin and geraniin (which are ellagitannins), whereas phyllanthin and hypophyllanthin have been suggested to be anti-inflammatory and antiapoptotic [45]. Possibly in the present study, this hepatoprotective property could not be evidenced due to the high quantity and or prolonged use of $P$. amarus. According to 
Hunaleyo et al [46] the administration of aqueous leaf extract of $P$. amarus in the dosage of 100, 200 and $400 \mathrm{mg}$ apparently restored the liver against garlic-induced damage in mature albino wistar rats. This present study is partly in consonance with Adomi et al [47] whose study revealed that acute oral administration of $P$. amarus extract is non-toxic to the rat liver, even at a dose of 5 and $8 \mathrm{~g} / \mathrm{kg}$ body weight respectively since the present study was administered protractedly. This study equally antagonized Ilangkovan et al [48] who administered doses of 100 to $500 \mathrm{mg} / \mathrm{kg}$ for 14 days and revealed non-toxic effect in rats and Lawson-Evi et al [49] and Kushwaha et al [50] who administered daily repeated doses of $P$. amarus for 28 days and had no morphological changes in histopathological observations of the kidney, liver, and pancreas in Swiss mice and Wistar rats. The present study is however, equally in consonance with Adedapo et al [51] and Manjrekar et al [52] whose histopathology studies in Wistar rats have shown that the kidney and liver are affected by the plant; these showed the toxic potential of the plant. This study also supports Singh et al [53] that associated slight cytotoxic effect to the human adenocarcinoma cell line to administration of $P$. amarus. With regard to the kidney, the possibility that the birds reacted to higher protein as $P$. amarus supplement gradually increased was evidenced since the plant via proximate analysis has been reported to contain $18.77 \pm 0.15 \%$ protein [54]. Age and diet may influence the concentration of blood uric acid in birds [55]. This might be that $P$. amarus has predilection for kidney no wonder it has been reported to possess antiurolithic property $[10 ; 11]$. The progressive increase in the blood UA and urea concentrations observed as PALM gradually increased could be as a result of an impaired kidney function associated with nephrotoxic potential of $P$. amarus [51]. Renal function in chickens is indicated by serum uric acid concentration. This is because the uric acid is the major nitrogenous end product of chickens excreted through the renal tubules into the urine [56]. UA is relatively inert and substantially less toxic in comparison to ammonia and urea. Uric acid (the oxidized form of purine - hypoxanthine) is mainly synthesized in the liver by the metabolism of purine [57]. UA is secreted in the proximal tubules of the cortical nephrons and approximately $90 \%$ of blood UA is removed by the kidneys. Therefore, serum or plasma UA levels have been widely used in the detection of kidney damages and disease. In general, UA greater than $13 \mathrm{mg} \mathrm{dL}^{-1}$ suggests impaired renal function in birds [28].

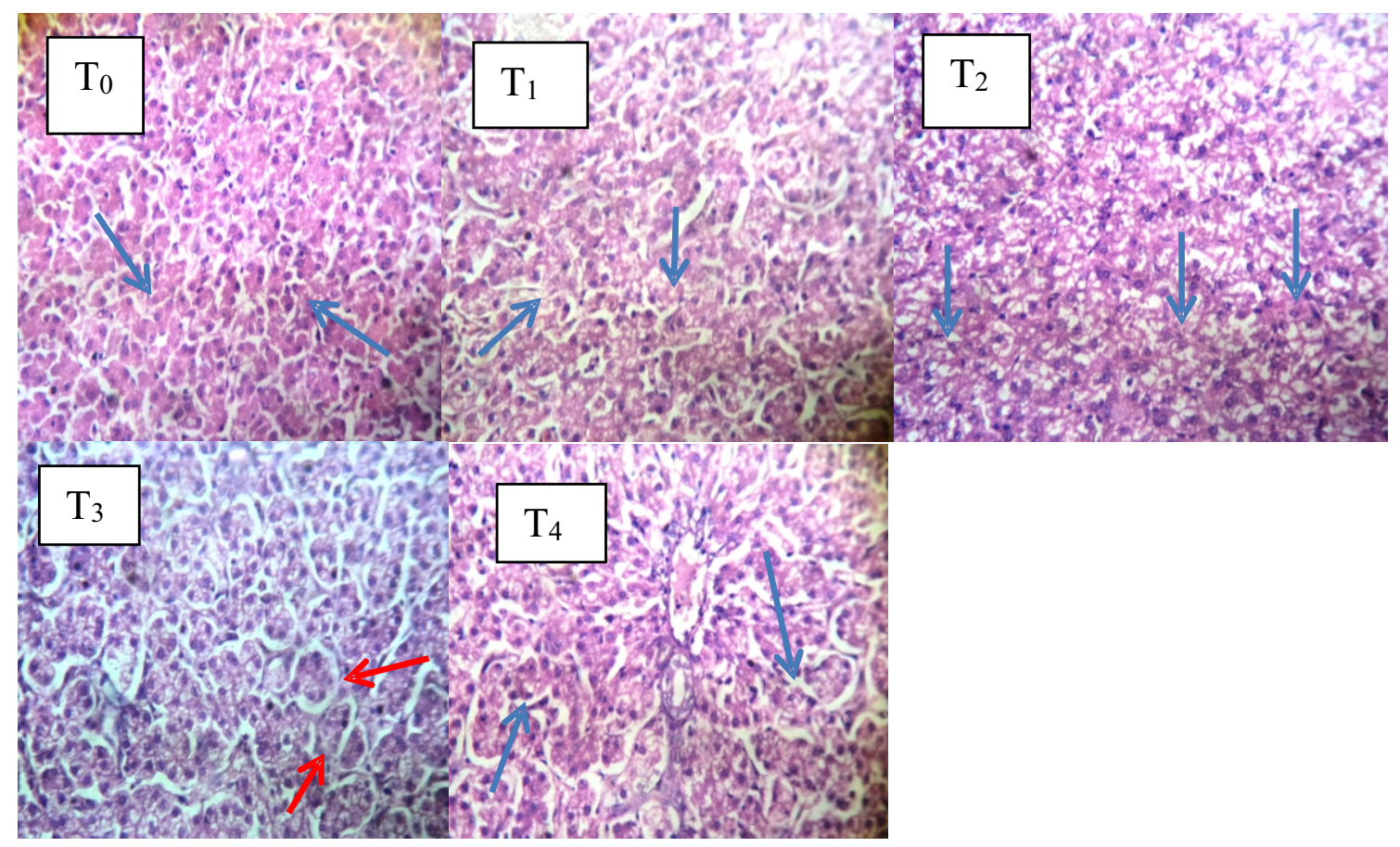


Fig. 1 (Liver): $\mathrm{T}_{0}$ (control), $\mathrm{T}_{1}(2.5 \mathrm{~g} / \mathrm{kg}), \mathrm{T}_{2}(5 \mathrm{~g} / \mathrm{kg}), \mathrm{T}_{3}(7.5 \mathrm{~g} / \mathrm{kg})$ and $\mathrm{T}_{4}(10 \mathrm{~g} / \mathrm{kg}$ PALM) [H\&E], [200X]

$\mathrm{T}_{0}$ : The hepatic plates are closely packed. Hepatocytes show no visible lesion

$\mathbf{T}_{1}$ : The hepatic plates are closely-packed. There is widespread moderate vacuolar change of hepatocytes

$\mathbf{T}_{2}$ : Hepatic plates are closely-packed. There are multiple foci of marked vacuolar change of hepatocytes.

$\mathbf{T}_{3}$ : The hepatic plates are closely-packed. Hepatocytes (arrows) have finely reticulated cytoplasmic appearance

$\mathbf{T}_{4}$ : The hepatic plates are closely-packed. Hepatocytes (arrows) have finely reticulated cytoplasmic appearance.

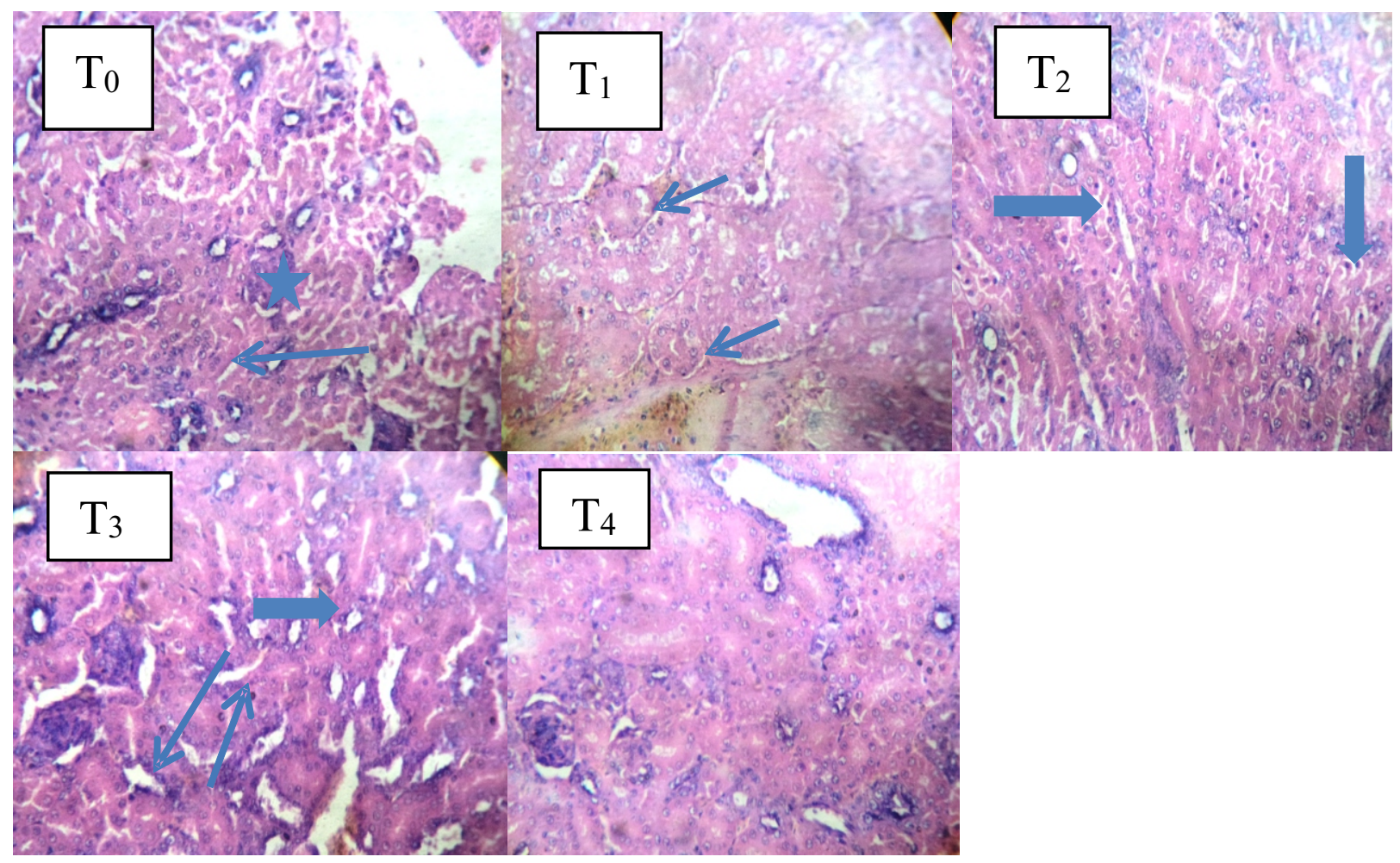

Fig. 2 (kidney): $\mathrm{T}_{0}$ (control), $\mathrm{T}_{1}(2.5 \mathrm{~g} / \mathrm{kg}), \mathrm{T}_{2}(5 \mathrm{~g} / \mathrm{kg}), \mathrm{T}_{3}(7.5 \mathrm{~g} / \mathrm{kg})$ and $\mathrm{T}_{4}(10 \mathrm{~g} / \mathrm{kg}$ PALM), $[\mathrm{H} \& \mathrm{E}],[200 \mathrm{X}]$

$\mathbf{T}_{\mathbf{0}}$ : The glomeruli (star) and tubules (arrows) appear normal. There are no remarkable vascular changes

$\mathbf{T}_{1}$ : The renal tubules (arrows) generally appear swollen (hydropic change)

$\mathbf{T}_{2}$ : There are multiple foci of tubular degeneration and necrosis (arrows).

$\mathbf{T}_{3}$ : There are a few foci of mild flattening of tubular epithelium (thin arrows). There is moderate congestion of interstitial blood vessels (thick arrow)

$\mathbf{T}_{4}$ : There is no visible lesion

\section{CONCLUSION}

P. amarus (crude) when administered for long at dose of $2.5 \mathrm{~g} / \mathrm{kg}$ or more could cause elevated enzymes used to monitor liver and kidney and as well distort the cyto-architecture of same organs. Therefore, despite the claim of offering protection to various tissues and organs $(53 ; 54 ; 55)$ of the body, its use should be with utmost caution. 


\section{REFERENCES}

1.Modzelewska, A., Kumar, S.K. and Khan, S.R. (2005). Sesquiterpenes: Natural products that decrease cancer growth. Current Medicinal Chemistry, 5:477-478.

2. Sandigawad, A.M. (2015). Traditional Applications and Phytochemical Investigations of Lonicera japonica Thunb. International Journal of Drug Development \& Research, 7: 47-54.

3. Edeoga, H.O., Omosun, G. and Awomukwu, D.A. (2006). Tannins and calcium oxalate crystals in lamina of some Phyllanthus species. International Journal of Molecular Medicine and Advance Sciences, 2: 326-329.

4. Etta, H. (2008) Effects of Phyllanthus amarus on litter traits in albino rats. Scientific Research and Essay, 3(8):370-372.

5. Peters, D.E. Omeodu, S.I. and Tege, E.B. (2015). Effect of ethanolic leaves extract of Phyllantus amarus on cisplatin induced nephrotoxicity in albino rats. Journal of Applied Science and Environmental Management, 19(4): 811-816.

6. Sangeeta, D., Romana, R. and Muneesh, K. (2017). Phytochemistry and pharmacological properties of Phyllanthus amarus Schum: A review. The Pharma Innovation Journal, 6(12): 169-172.

7. Meena, J., Sharma, R.A. and Rolania, R. (2018). A review on phytochemical and pharmacological properties of Phyllanthus amarus Schum. and Thonn. International Journal of Pharaceutical Science Research, 9(4): 1377-86.

8. Tahseen, M. and Mishra, G. (2013). Ethnobotany and Diuretic Activity of Some Selected Indian Medicinal Plants. The Pharma Innovation, 2:112-116.

9. Patel, J.R. Tripathi, P., Sharma, V., Chauhan, N.S. and Dixit, V.K. (2011). Phyllanthus amarus Ethnomedicinal uses phytochemistry and pharmacology: A review. Journal of Ethnopharmacology, 138(2):286-313.

10. Sen, A. and Batra, A. (2013). The study of in vitro and in vivo antioxidant activity and total phenolic content of Phyllanthus amarus Schum Thonn: A medicinally important plant. International Journal of Pharmacy and Pharmaceutical Sciences, 5:947-951.

11. Ushie, O., Neji, P. and Etim, E. (2013).
Phytochemical screening and antimicrobial activities of Phyllanthus amarus stem bark extracts. International Journal of Modern Biology and Medicines, 3:101-112.

12. Taylor, L. (2003). Herbal Secrets of the Rainforest. 2nd edn, Sage Press, Newyork, Inc., p53.

13. Gafar, M.K., Itodo, A.U. and Senchi, D.S. (2012). Nutritive and anti-nutritive composition of Chanca piedra (stone breaker). Food and Public Health, 2(2):21-27.

14. Ogbuewu, I.P., Okoli, I.C., and Iloeje, M.U. (2010). Evaluation of toxicological effect of leaf meal on an ethnomedicinal plantneem on blood chemistry of puberal chinchilla rabbit does. Reports and Opinion, 2(2):29-34.

15. Oladele, B.M. and Oladimeji, B.H. (2011). Dynamics of urban land use changes with remote sensing: Case study of Ibadan, Nigeria. Journal of Geography and Regional Planning, 4(11): 632-643.

16. Egbinola, C.N. and Amobichukwu, A.C. (2013). Climate variation assessment based on rainfall and temperature in Ibadan, SouthWestern, Nigeria. Journal of Environment and Earth Science, 3(11): 32-45.

17. Ward, J.W. and Elsea, J.R. (1997). Animal case and use in drug fate and metabolism, methods and techniques. Vol. 2. New York: Marcel Deker; pp. 431.

18. Okeudo, N., Okoli, I.C. and Igwe, G.O.F. (2003). Haematological characteristics of ducks (Carina moschata) of South Eastern Nigeria. Tropicultura, 21:61-65.

19. Drury, R.A.B., Wallington, E.A. and Cameron, R. (1967). Carleton's Histological Techniques. 4th ed. NY. USA: Oxford Univ. Press; 280.

20. Ewuola, E.O. (2009). Organ traits and histopathology of rabbits fed varied levels of dietary fumonisin $\mathrm{B}_{1}$. Journal of Animal Physiology and Animal Nutrition, 93: 726731.

21. Duncan, D.B. (1955). Multiple Range and Multiple F- Tests" Biometrics, 11: 1-42. http://dx.doi.org/10.2307/3001478

22. Bashir, L., Shittu, O.K., Busari, M.B., Sani, S. and Aisha, M.I. (2015). Safety evaluation of giant African land snails (Archachatina maginata) haemolymph on hematological and biochemical parameters of Albino rats. 
Journal of Advanced Medical Pharmaceutical Science, 3(3): 122-30.

23. Akande, T.O., Odunsi, A.A., Rafiu, T.A., Olaniyi, C.O. and Binuomote, R.T. (2013). Growth and serological assessment of broiler chickens fed differently processed castor (Ricinus communis Linn.) kernel cake based diets. African Journal of Agricultural Research, 8(41): 5161-5165.

24. Murray, R.K., Granner, D.K., Mayes, P.A. and Rodwell, V.W. (1990). Harper's Biochemistry (Harper's Illustrated Biochemistry), 22nd edition. Appleton and Lange, USA, pp 447.

25. Mansour, H.A., Newairy, A.S., Yousef, M.I. and Sheweita, S.A. (2002). Biochemical study on the effects of some Egyptian herbs in alloxan-induced diabetic rats. Toxicology, 170: 221-228.

26. Khan, R.U., Rehman, Z., Javed, I. and Muhammad, F. (2013). Supplementation of vitamins, probiotics and proteins on oxidative stress, enzymes and hormones in post-moult male broiler breeders. Archiv. Tierzucht., 61: 607-616.

27. Elagib, H.A.A., Nabiela, E.M., Abbass, S.A. and Ginawi, T.A.N. (2012). Effect of Natural Spices on Plasma Proteins in Broiler Chicks. Journal of Nutrition and Food Science, 2:152-57.

28. Thrall, M.A., Weiser, G., Allison, R.W. and Campbell, T.W. (2012). Veterinary hematology and clinical chemistry. 2nd ed. Danvers : Wiley-Blackwell, pp 204.

29. Kuttappan, V.A., Huff, G.R., Huff, W.E., Hargis, B.M., Apple, J.K. and Coon, C. (2013). Comparison of hematologic and serologic profiles of broiler birds with normal and severe degrees of white striping in breast fillets. Poultry Science, 92:339-345.

30. Obianime, A.W. and Uche, F.I. (2008). The phytochemical screening and the effects of methanolic extract of Phyllanthus amarus leaf on the biochemical parameters of male guinea pigs. Journal of Applied Sciences and Environmental Management, 12:73-77.

31. Matthews, H.B., Lucier, G.W. and Fisher, K.D. (1999). Medicinal herbs in the United States: Research Needs. Environ Health Perspect., 107: 773-778

32. Mihaich, E.M., Schäfers, C., Dreier D.A.,
Hecker, M., Ortego, L., Kawashima, Y., Dang, Z. and Solomon, k. (2017). Challenges in assigning endocrine-specific modes of action: Recommendations for researchers and regulators. Integrated Environmental Assessment and Management, 13(2): 280-292. https://doi.org/10.1002/ieam.1883

33. Wolf, J.C., and Wheeler, J.R. (2018) A critical review of histo-pathological findings associated with endocrine and non-endocrine hepatic toxicity in fish model. Aquatic Toxicology, 197(2018): 60-78.

34. Oloruntola, O.D. (2018) Serum biochemistry and histological studies in growing rabbits fed diets supplemented with Mucuna pruriens leaf meal. Arch. Current Res. Int. 15(1): 1-10.

35. Soetan, K.O. and Oyewole, O.E. (2009) The need for adequate processing to reduce the antinutritional factors in plants used as human foods and animal feeds: A review. African $J$. Food Sci., 3(9): 223-232.

36. Corduk, M., Ceylan N. and Ildiz, F. (2007). Effects of dietary energy density and Lcarnitine supplementation on growth performance, carcass traits and blood parameters of broiler chickens. S. Afr. J. Anim. Sci., 37: 65-73.

37. Nayak, N.C., Sathar, S.A., Mughal, S., Duttagupta, S., Mathur, M., and Chopra, P. (1996). The nature and significance of liver cell vacuolation following hepatocellular injury-an analysis based on observations on rats rendered tolerant to hepatotoxic damage. Virchows Arch., 428(6): 353-65. doi: 10.1007/BF00202202

38. Jain, E., Damania, A. and Kumar, A. (2014). Biomaterials for liver tissue engineering. Hepatol. Int., 8: 185-197. 10.1007/s12072-013-9503-7

39. Krithika, R. and Verma, R.J. (2009). Mitigation of carbon tetrachloride-induced damage by Phyllanthus amarus in liver of mice. Acta Pol. Pharmaceuticals, 66(4): 439-444.

40. Atici, S., Cinel, I., Cinel, L., Doruk, N., Eskandari, G. and Oral, U. (2005). Liver and kidney toxicity in chronic use of opioids: An experimental long term treatment model. Journal of Biosciences, 30: 245-52. 
41. Perry, L.M. (1980). Medicinal plants of East and South East Asia. Cambridge Massachusetts: MIT Press.

42. Farber, J.L., Chein, K.R. and Mittnacht, S. (1981). The pathogenesis of irreversible cell injury in ischemia. American Journal of Pathology, 102: 271-281.

43. Srirama, R., Deepak, H.B. and Senthilkumar, U. (2012). "Hepatoprotective activity of Indian Phyllanthus," Pharmaceutical Biology, 50 (8) 948-953.

44. Londhe, J.S., Devasagayam, T.P.A. and Foo, L.Y. (2012). "Geraniin and amariin, ellagitannins from Phyllanthus amarus, protect liver cells against ethanol induced cytotoxicity," Fitoterapia, 83(8): 1562-1568. 45. Kandhare, A.D., Ghosh, P. and Ghule, A.E. (2013). "Protective effect of Phyllanthus amarus by modulation of endogenous biomarkers and DNA damage in acetic acid induced ulcerative colitis: role of phyllanthin and hypophyllanthin,". Apollo Medicine, 10 (1): 87-97.

46. Hunaleyo, H.F., Buratai, L.B., Mofio, B.M., Lawan, H.K. and Abdulrahman, A.A. (2017). Effects of Phyllanthus amarus on garlicinduced hepatotoxicity. Nigerian Journal of Health Sciences, 17: 53-8.

47. Adomi, P.O., Owhe-Ureghe, U.B. and Asagba, S.O. (2017). Evaluation of the toxicity of Phyllanthus amarus in wistar albino rats. African Journal of Cellular Pathology, 8: 2735.

48. Ilangkovan, M., Jantan, I., Mesaik, M.A.

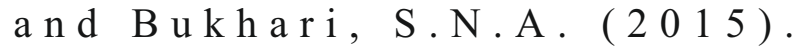
Immunosuppressive effects of the standardized extract of Phyllanthus amarus on cellular immune responses in Wistar- Kyoto rats. Drug Des. Development Ther., 9: 4917. doi: 10.2147/DDDT.S88189

49. Lawson-Evi, P., Eklu-Gadegbeku, K. and Agbonon, A. (2008). Toxicological assessment on extracts of Phyllanthus amarus Schum and Thonn. Science Research Essays, 3:410-415.

50. Kushwaha, S.K., Dashora, A., Dashora, N., Patel, J.R. and Kori, M.L. (2013). Acute oral toxicity studies of the standardized methanolic extract of Phyllanthus amarus Schum \& Thonn.
Journal of Pharmaceutical Research, 67: 720724. doi: 10.1016/j.jopr.2013.04.020

51. Adedapo, A.A., Adegbayibi, A.Y. and Emikpe, B.O. (2005). Some clinicopathological changes associated with the aqueous extract of the leaves of Phyllanthus amarus in rats. Phytotherapy Research, 19:971-976.

52. Manjrekar, A.P., Jisha, V., Bag, P.P., Adhikary, B., Pai, M.M. and Hegde, A. (2008). Effect of Phyllanthus niruri Linn treatment on liver, kidney and testes in CCl4 induced hepatotoxic rats. Indian Journal of Experimental Biology, 46:514-520.

53. Singh, T., Kumar, R. and Singh, J.K. (2016). Acute toxicity study of Phyllanthus niruri and its effect on the cyto-architectural structure of nephrocytes in Swiss albino mice Mus musculus. Pharmacognosy Journal, 8(1): 5661.

54. Okiki, P.A., Olatunji, B.P., Egbebi, A.S. and Ojo, C. (2015). A comparative study of nutritional and phytochemical composition of Phyllanthus amarus leaf and seed. AmericanEurasian Journal of Toxicological Sciences, 7(4): 321-327.

55. Kalita, D., Sultana, R., Roy, M. and Bharali, K. (2018). Comparative Study of Certain Biochemical Profile of Broiler and Indigenous Chicken of Assam. Appro. Poultry Dairy and Veterinary Sciences, 2(4):175-177.

56. Sturkie, P.D. (1986). Body fluids: Blood. In: Sturkie, P.D (Ed), Avian Physiology. 4th Edn., Springer-Verlag Berlin., pp.320.

57. Harr, K.E. (2006). Diagnostic value of biochemistry. In: Harrison GJ, Lightfoot T, eds. Clinical avian medicine. Volume II. Palm Beach : Spix Publishing, 611-30. 